\title{
Effects of blends of camel and calf chymosin on proteolysis, residual coagulant activity, microstructure, and sensory characteristics of Beyaz peynir
}

\author{
P. Gumus ${ }^{1}$ and A. A. Hayaloglu ${ }^{2 *}$ \\ ${ }^{1}$ Department of Food Engineering, Kilis 7 Aralık University, 79000 Kilis, Turkey \\ ${ }^{2}$ Department of Food Engineering, Inonu University, 44280 Malatya, Turkey
}

\begin{abstract}
Beyaz peynir, a white brined cheese, was manufactured using different blends of camel chymosin (100, $75,50,25$, and $0 \%$ ) with calf chymosin and ripened for $90 \mathrm{~d}$. The purpose of this study was to determine the best mixture of coagulant for Beyaz peynir, in terms of proteolysis, texture, and melting characteristics. The cheeses were evaluated in terms of chemical composition, levels of proteolysis, total free amino acids, texture, meltability, residual coagulant activity, microstructure, and sensory properties during $90 \mathrm{~d}$ of ripening. Differences in the gross chemical composition were statistically significant for all types of cheeses. Levels of proteolysis were highly dependent on the blends of the coagulants. Higher proteolysis was observed in cheeses that used a higher ratio of calf chymosin. Differences in urea-PAGE and peptide profiles of each cheese were observed as well. Meltability values proportionally increased with the higher increasing levels of calf chymosin in the blend formula. These coagulants had a slight effect on the microstructure of cheeses. The cheese made with camel chymosin had a harder texture than calf chymosin cheese, and hardness values of all cheese samples decreased during ripening. The cheeses with a high ratio of calf chymosin had higher residual enzyme activity than those made with camel chymosin. No significant difference in sensory properties was observed among the cheeses. In conclusion, cheeses made with a high level of calf chymosin had a higher level of proteolysis, residual coagulant activity, and meltability. The cheeses also had a softer texture than cheeses made with a high content of camel chymosin. Camel chymosin may be used as a coagulant alone if low or limited levels of proteolysis are desired in cheese.
\end{abstract}

Received September 10, 2018.

Accepted March 18, 2019.

*Corresponding author: adnan.hayaloglu@inonu.edu.tr
Key words: camel and calf chymosin, white brined cheese, Beyaz peynir, proteolysis

\section{INTRODUCTION}

Rennet is the general term for a milk-coagulating enzymatic preparation consisting of coagulants, proteases, or proteinases of animal, plant, or microbial origin that is used to coagulate milk in cheese production (Bansal et al., 2007; Ahmed et al., 2016). $\kappa$-Casein is cleaved at the $\mathrm{Phe}_{105}-\mathrm{Met}_{106}$ bond by rennet containing 2 major acid proteolytic enzymes such as chymosin and pepsin remaining in the fourth abomasum of sucking ruminants (Bruno et al., 2010; Moschopoulou, 2011). The amount and presence of chymosin or other enzymes are important in the cheese ripening. The major roles of chymosin, which is the major component of rennet, are to coagulate milk, destabilize the casein micelle, and improve proteolysis (Kumar et al., 2006; Bansal et al., 2009b; Akkerman et al., 2017).

Various clotting enzymes such as calf rennet have been used for years in cheese production. However, alternative milk-clotting enzymes are being researched for several reasons, such as a lack of calf rennet available on the world market and the high cost. Calf chymosin has been replaced by proteinases from other animals or microorganisms (Cepoglu and Güler-Akın, 2013; Hayaloglu et al., 2014). As one of many advances in recombinant DNA technology, the gene for calf chymosin has been cloned into microorganisms, and fermentation-produced chymosin is a common enzyme used in cheese production in recent studies (Bansal et al., 2009a).

Cheese made from calf chymosin demonstrates higher primary proteolysis than cheese made using camel chymosin, which is attributed to both the lower amount of camel chymosin added and lower general proteolytic activity during cheese ripening (Moynihan et al., 2014). Fermentation-produced camel chymosin has a $70 \%$ higher milk-clotting activity per mole in 
bovine milk than calf chymosin, and this is due to the higher specificity of camel chymosin on the $\mathrm{Phe}_{105^{-}}$ Meth $_{106}$ bond compared with calf chymosin. Therefore, the milk-clotting and general proteolytic activities of the coagulant have been compared with calf chymosin. However, the general proteolytic activity, which is the ability to cleave any bond in casein (not milk clotting), of camel chymosin is only $25 \%$ that of bovine chymosin (Kappeler et al., 2006; Møller et al., 2012). Therefore, the milk-clotting and proteolytic activity of camel chymosin and bovine chymosin on cheese making were compared by Jensen et al. (2013) and Borsting et al. (2014). Jensen et al. (2013) noted that calf and camel chymosin possess local positively charged patches on their surface, which may play a role in interactions with the overall negatively charged C-terminus of $\kappa$-casein. Camel chymosin contains 2 additional positive patches that favor interaction with the substrate. The improved electrostatic interactions and substrate binding contribute to the better milk-clotting activity of camel chymosin toward bovine milk (Jensen et al., 2013). Borsting et al. (2014) found that the milk pH dependence for retention of camel chymosin is lower than that of bovine chymosin due to a lower negative charge of the camel chymosin molecule.

Residual milk-clotting enzyme retained in cheese curd plays the main role in proteolysis and affects the texture and flavor of cheese during ripening (Hynes et al., 2004; Bansal et al., 2007, 2009b). A residual coagulant is thought to be associated with cheese softening by hydrolysis of $\mathrm{Phe}_{23}-\mathrm{Phe}_{24}$ bond of $\alpha_{\mathrm{S}_{1}}$-casein. Many factors affect the level of coagulant retained in cheese curd. These include the types of cheese and coagulant, the $\mathrm{pH}$ and temperature stability of the coagulant, the cheese-making procedure, level of casein, heat treatment of milk, and types and ratio of coagulant in the cheese (Hurley et al., 1999; Bansal et al., 2007, 2009a).

Bansal et al. (2009a) indicated that the milk-clotting activity of camel chymosin is superior. However, its general proteolytic activity is weak. The milk-clotting activity of camel chymosin is high and it provides some advantages in cheese production. In the manufacture and ripening of Beyaz peynir, the milk-clotting stage should be completed within approximately $90 \mathrm{~min}$ and the ripening index approximately 15 to $20 \%$ for water-soluble nitrogen or 10 to $15 \%$ for $\mathrm{pH} 4.6$-soluble nitrogen (as \% of total nitrogen). The cheese, which is not an extra-ripened variety, is ripened under brine for about 3 to 4 mo. The combination of these advantages is a higher clotting and lower proteolytic activities for camel chymosin than for calf chymosin. This phenomenon is the primary objective and the main hypothesis of this study. In this study, we compared the performance and proteolytic ability of calf and camel chymosins dur- ing cheese making and ripening. To determine the best mixture of coagulant, different blends $(100,75,50,25$, and $0 \%$ ) of camel chymosin and calf chymosin were used to produce Beyaz peynir. The chemical composition, proteolysis, meltability, texture, sensory evaluations, microstructure, and residual coagulant activity were analyzed.

\section{MATERIALS AND METHODS}

\section{Materials}

Raw cow milk (100 L) was supplied from a local dairy plant in Malatya (Turkey). Salt and plastic box was obtained from local markets. Cheese starter culture (Valiren C100, Mayasan AS, Istanbul, Turkey), calf chymosin [200 international milk clotting units (IMCU), Naturen, Chr. Hansen, Istanbul, Turkey], and camel chymosin (1,000 IMCU, CHY-MAX M, Chr. Hansen) were supplied from elsewhere.

\section{Cheese Manufacture}

Two cheese-making trials were carried out in the manufacture of Beyaz peynir using raw cow milk (100 L). The milk was divided into 5 batches and these batches were converted to cheese as described in Hayaloglu et al. (2002). The milk was heated at $68^{\circ} \mathrm{C}$ for $10 \mathrm{~min}$ and then cooled to $32^{\circ} \mathrm{C}$. The different blends of camel chymosin $(100,75,50,25$, and $0 \%)$ with calf chymosin were used to make Beyaz peynir. Starter cultures (1\%) propagated in reconstituted milk $10 \%$ (wt/wt) and calcium chloride $\left(20 \mathrm{~g}\right.$ of $\mathrm{CaCl}_{2} / 100 \mathrm{~kg}$ of milk) were added to the pasteurized milk at the same temperature. Milk was pre-ripened using starter culture for 30 to 45 min (until pH 6.3). Then, 5 different blends of camel and calf chymosin $[100 \%$ (A100), $75 \%$ (A75), $50 \%$ (A50), 25\% (A25), and 0\% (A0)] were added at levels of $1.50,1.55,1.87,2.08$, and $5.55 \mathrm{~mL}$ per 20 $\mathrm{kg}$ of milk, respectively. The coagulant blends were added to each batch (20 L of pasteurized cow milk) according to IMCU values of camel and calf chymosin. After the complete coagulation of milk in the batches, the coagulum was cut and rested for about 15 to 20 min. The curd was stirred at 5 to 6 min intervals and then rested for $15 \mathrm{~min}$. The precipitated curd was then transferred into wooden molds. The curd was pressed to separate the whey and form the curd. Then, fresh cheeses were cut with a knife into blocks $(7.5 \times 7.5$ $\times 7.5 \mathrm{~cm})$ and kept in a brine solution $(12 \% \mathrm{NaCl}$, wt/vol) overnight at $25^{\circ} \mathrm{C}$. Each of the cheese blocks (molds) weighed about $500 \mathrm{~g}$. After the initial brining, the cheese blocks were ripened in a plastic box, with a hermetically sealed lid, containing $12 \% \mathrm{NaCl}$ at $7^{\circ} \mathrm{C}$. 
The cheese samples were analyzed in duplicate during $90 \mathrm{~d}$ of ripening in $30-\mathrm{d}$ intervals.

\section{Chemical Composition}

The cheese samples were tested for the $\mathrm{pH}$ and moisture, total protein, fat, and salt contents using the methods described by Hayaloglu et al. (2005).

\section{Proteolysis}

The methods described by Hayaloglu et al. (2005) were used to test the $\mathrm{pH}$ 4.6-soluble nitrogen (4.6-SN) and $12 \%$ trichloroacetic acid-soluble nitrogen (TCASN) fractions of cheese, urea-PAGE of caseins and the reversed-phase (RP) HPLC of the peptides. The urea-PAGE gels scanned through HP Scan Jet G4010 (Hewlett Packard, Palo Alto, CA) were measured with densitometric software (Image Master Total Lab Phonetix 1 D Pro-software, Newcastle upon Tyne, UK). The caseins were detected quantitatively by integrating peak volumes with the densitometer (Hayaloglu et al., 2014). The total concentration of free amino acids (FAA) in the cheese products was ascertained in triplicate as described by Hayaloglu et al. (2005). Results were reported as milligrams of Leu per gram of cheese.

\section{Texture Profile Analysis, Meltability, and Microstructure}

The texture profile analysis (hardness and gumminess) and meltability of the cheese samples were performed after 1, 30, 60, and $90 \mathrm{~d}$ of ripening by the methods as described by Hayaloglu et al. (2014).

The microstructure of the cheeses was detected at the beginning of ripening as shown by Oluk et al. (2014). Images of the pieces were screened by a high vacuum Scanning Electron Microscopy (LEO, EVO 40, Carl Zeiss SMT, Oberkochen, Germany).

\section{Residual Coagulant Activity}

Residual coagulant activity was determined using the method described by Hurley et al. (1999) with slight modification. Five milligrams of grated cheese was dispersed in $1 \mathrm{~mL}$ of $0.1 \mathrm{M}$ trisodium citrate buffer $(\mathrm{pH} 7.0)$, then incubated at $37^{\circ} \mathrm{C}$ for $30 \mathrm{~min}$ with periodical stirring. The fat layer was then separated by centrifugation $(1,000 \times g$ for $1 \mathrm{~min})$. An aliquot of $140 \mu \mathrm{L}$ of cheese dispersion was mixed with $400 \mu \mathrm{L}$ of $0.1 M$ sodium formate ( $\mathrm{pH} \mathrm{3.2)} \mathrm{and} 30 \mu \mathrm{L}$ of the substrate dilution $(1 \mathrm{mg} / \mathrm{mL}$ of the synthetic heptapeptide H-Pro-Thr-Clu-Phe-[p-nitro-Phe]-Arg-Leu-OH, H-1002, Bachem AG, Bubendorf, Switzerland). After incubation at $37^{\circ} \mathrm{C}$ for $1 \mathrm{~h}$, the enzymatic reaction was terminated by heat treatment at $70^{\circ} \mathrm{C}$ for $10 \mathrm{~min}$. The assay mixture was then centrifuged (Hettich Model 320 $\mathrm{R}$, Tutlingen, Germany) at $16,000 \times g$ for $10 \mathrm{~min}$ and $100 \mu \mathrm{L}$ of the supernatant filtered through a $0.45-\mu \mathrm{m}$ syringe filter. The filtrate was injected into a Shimadzu LC-20AD Prominence HPLC system (Shimadzu Corp., Kyoto, Japan) consisting of a diode array detector model SPD-M20A equipped with a pump system with an auto sampler model SIL-20A HT, CTO-20A column heater, and DGU-20A5 degasser units. A gradient solvent system consisting of $0.1 \%$ trifluoroacetic acid in HPLC-grade water (solvent A) and $0.1 \%$ trifluoroacetic acid in acetonitrile (Merck, Darmstadt, Germany) as solvent B was used for separation at $300 \mathrm{~nm}$ using a C8 $\mathrm{RP}$ column with size of $250 \times 4.6 \mathrm{~mm}, 300 \AA$ pore size, $5 \mu \mathrm{m}$ particle (Inertsil, WP 300, GL Science, Tokyo, Japan). Other chromatographic conditions were the same as in Hurley et al. (1999). The residual coagulant activities of the cheeses were expressed as peak area units per milligram of cheese DM per hour.

\section{Sensory Analysis}

Sensory evaluation of the cheese products was performed after $1,30,60$, and $90 \mathrm{~d}$ of ripening. Five different types of cheese samples were presented to 7 panelists for a sensory evaluation at 2 separate sessions. Before each session, the cheeses were rested for about $60 \mathrm{~min}$ at room temperature. About $200 \mathrm{~g}$ of each sample was presented to each panelist. Water and salty crackers were also provided. The samples were evaluated according to the following criteria: color and appearance (scale 0-5), body and texture (scale 0-5), taste and flavor (scale 0-10), and overall quality (scale $0-5)$. All members of the panel were on the staff of the Department of Food Engineering, Inonu University, Turkey, and were familiar with the taste and texture of Beyaz peynir (Sahingil et al., 2014).

\section{Statistical Analysis}

The ANOVA was carried out by the General Linear Model (GLM) procedure of SAS version 6.12 (SAS Institute Inc., Cary, NC). Duncan's multiple comparison tests were used as a guide for paired comparisons of treatment means. The level of significance of differences between treatments was detected at $P<0.05$. Data from the RP-HPLC chromatograms of the $\mathrm{pH}$ 4.6-soluble fractions of the cheeses were analyzed using multivariate statistical techniques to simplify interpretation of the data from RP-HPLC. Principal component analysis (PCA) was performed using a covariance matrix and varimax rotation between the cheeses. The 
Table 1. Chemical composition and $\mathrm{pH}$ values of Beyaz peynir made using different blends of coagulant ${ }^{1}$ during $90 \mathrm{~d}$ of ripening

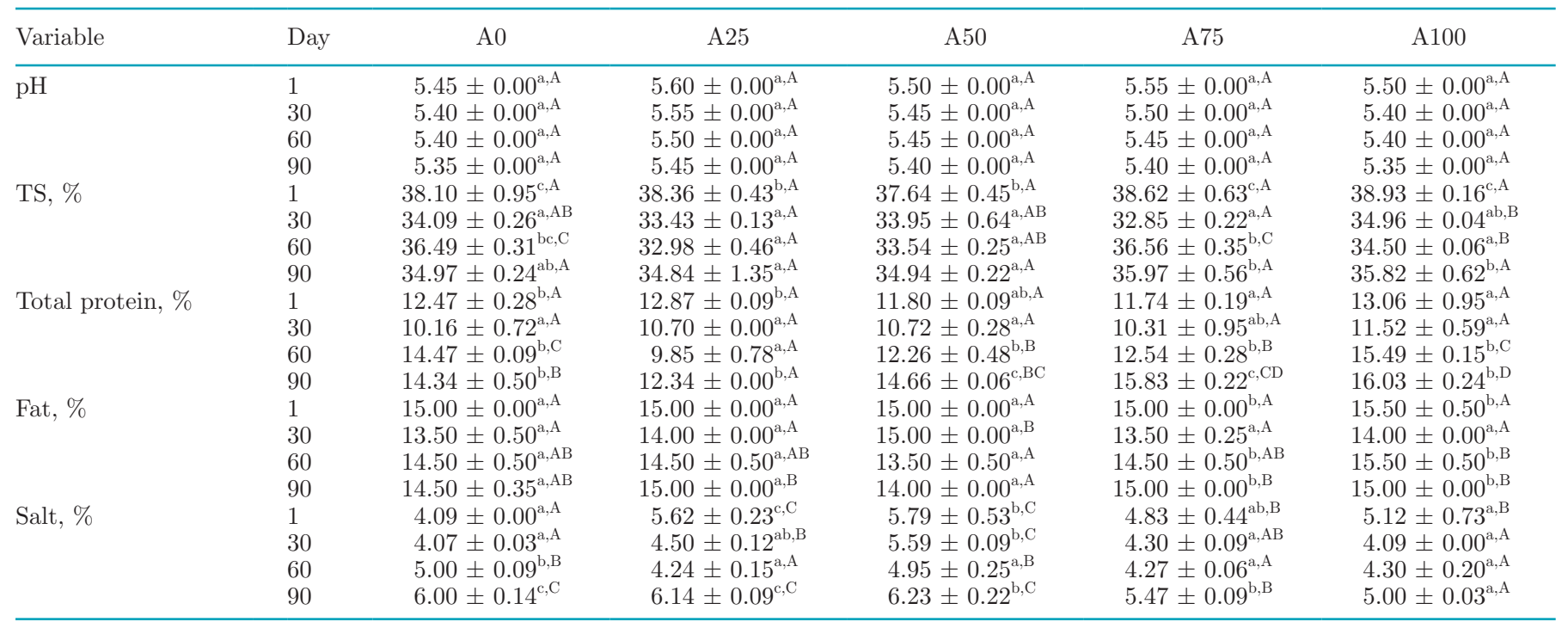

\footnotetext{
${ }^{a-c}$ Means in the same column followed by different lowercase letters represent significant differences $(P<0.05)$.

${ }^{\mathrm{A}-\mathrm{D}}$ Means in the same row followed by different uppercase letters represent significant differences $(P<0.05)$.

${ }^{1} \mathrm{~A} 0=100 \%$ camel chymosin $+0 \%$ calf rennet; A $25=75 \%$ camel chymosin $+25 \%$ calf rennet; A $50=50 \%$ camel chymosin $+50 \%$ calf rennet; $\mathrm{A} 75=25 \%$ camel chymosin $+75 \%$ calf rennet; and A100 $=0 \%$ camel chymosin $+100 \%$ calf rennet.
}

peak heights (from RP-HPLC chromatographic data) were used as variables and PCA was carried out using SPSS package program version 9.0 for Windows (SPSS Inc., Chicago, IL).

\section{RESULTS AND DISCUSSION}

\section{Chemical Composition and $\mathrm{pH}$}

Changes in chemical composition and $\mathrm{pH}$ of Beyaz peynir during $90 \mathrm{~d}$ of ripening are shown in Table 1. Significant differences were observed between lactic acid and fat contents of the cheese samples; however, similar results were determined in terms of TS and salt content in these cheeses at the first stage of ripening. Small differences in fat contents in cheeses were not related to the type or level of coagulant or ripening time. As ripening progressed, differences increased between the chemical composition values of the samples during ripening $(P<0.05)$. The $\mathrm{pH}$ of cheese samples ranged from 5.45 to 5.60 on the first day of ripening, and the $\mathrm{pH}$ of the cheeses was close to 5.40 in aged cheeses. Total solids, protein, salt, and fat contents of the cheeses are in accordance with previously reported results (Hayaloglu et al., 2005; Cepoglu and GülerAkın, 2013). Use of the different blends of camel and calf chymosin resulted in significant changes in the chemical composition and $\mathrm{pH}$ of the cheeses after $30 \mathrm{~d}$ of ripening $(P<0.05)$. At the beginning of ripening, $\mathrm{pH}$, TS, fat, and salt contents of the cheese were almost identical in all samples; however, differences in the samples increased by ripening time, probably due to the mass transfer from the cheese mass to brine or vice versa during the ripening process (Hayaloglu, 2017). In some studies, the use of different coagulants does not cause any change in cheese composition (Alichanidis et al., 1984; O'Mahony et al., 2003); however, some researchers (Lane et al., 1997; Yasar and Güzeler, 2011) reported that milk-clotting enzymes have a significant effect on the chemical composition of the cheeses.

\section{Proteolysis}

Total nitrogen values of Beyaz peynir produced using different blends of coagulants are shown in Table 2 during $90 \mathrm{~d}$ of storage. No statistical difference was found between the nitrogen content of cheeses produced using different proportions of coagulants in the first 30 d. However, differences began to emerge on d 60 and continued to increase until d 90 ripening $(P<$ 0.05). In another study, no significant differences were detected in protein levels in the first $30 \mathrm{~d}$ of ripening. An increase in the values was observed after $60 \mathrm{~d}$ of ripening (Yasar and Güzeler, 2011). The levels of $\mathrm{pH}$ 4.6-SN in Beyaz peynir produced using different ratios of coagulating enzyme are shown in Table 2 . The levels of $\mathrm{pH}$ 4.6-SN ratios for all cheeses increased (from $3.46-4.39 \%$ to $11.46-13.16 \%$ for 1 and $90 \mathrm{~d}$ of ripening, respectively) significantly during ripening as shown in other studies (O'Mahony et al., 2003; Moynihan et al., 
2014). Cheese made with a higher level of calf chymosin resulted in a higher $\mathrm{pH}$ 4.6-SN values compared with cheese that contained higher rates of camel chymosin at $90 \mathrm{~d}$ of ripening. This is because calf chymosin has higher proteolytic activity than camel chymosin when tested in the different types of cheeses (Kappeler et al., 2006; Bansal et al., 2009a). Moynihan et al. (2014) studied Mozzarella cheese produced using camel and calf chymosin, and reported that camel chymosin has low proteolytic activity and the amount of camel chymosin added to cheese proteolysis plays no significant role on the proteolysis of the cheese.

Table 2 shows the levels of TCA-SN in Beyaz peynir during $90 \mathrm{~d}$ of ripening and how different blends of coagulants changed the levels of TCA-SN during ripening $(P<0.05)$, as reported in other studies (Sousa and Malcata, 1997; Hayaloglu et al., 2005). As for pH 4.6-SN values, calf chymosin had a stronger effect on soluble nitrogen values in $12 \%$ TCA than camel chymosin (Table 2 ). In contrast, $12 \%$ TCA-SN depends on the activity of proteolytic and peptidolytic enzymes of lactic acid bacteria rather than the activity of coagulant enzymes. As ripening proceeded, these values showed a constant increase and the differences became pronounced. The lowest and highest $12 \%$ TCA-SN values were obtained after 1 and $90 \mathrm{~d}$ of ripening, respectively. Because the TCA-SN fraction contains small and intermediate peptides, the level of TCA-SN increases during ripening by proteolysis (Sousa et al., 2001). Use of different blends of camel and calf chymosin in the manufacture of Beyaz peynir changed the level of $12 \%$ TCA-SN values, result- ing in significant differences between the cheeses. The level of TCA-SN was higher in cheese A75 than the other cheeses after 1, 60, and $90 \mathrm{~d}$ of ripening (Table 2 ). This increase can be explained by its higher level of calf chymosin.

Peptide profiles of Beyaz peynir were determined by RP-HPLC during $90 \mathrm{~d}$ of ripening (Figure 1), with slight differences, which are shown with arrows on the chromatogram, being observed between the peptide profiles of the cheeses after $90 \mathrm{~d}$ of ripening. These differences indicate that calf and camel chymosins contribute to proteolysis in different ways. The blends of coagulants produced mostly the same types of peptides with slight differences; however, the peak heights were different, as shown in Figures 1 and 2, in which the PCA of the data helped to clarify the separation of the cheese samples and interpretation of the results. Some researchers have noted that each coagulating enzyme produces different peptide profiles in cheese during ripening (Sousa and Malcata, 1997; Lane et al., 1997; O'Mahony et al., 2003). These differences have resulted in each coagulating enzyme having different cleavage on peptide bonds of the casein and casein-derived peptides during cheese production and ripening (Lane et al., 1997; Broome and Limsowtin, 1998). Principal component (PC) analysis was run for peak height of all peptides eluted in the chromatogram after $60 \mathrm{~d}$ of ripening. The PC1 and PC2 accounted for 54.6 and $20.9 \%$ accounted for the total variance, respectively (Figure 2). The PCA of the RP-HPLC peptide profiles of the cheeses showed that the cheeses were grouped by the composition of the

Table 2. The levels of proteolysis, total free amino acids (FAA), and residual coagulant activity values in Beyaz peynir made using different blends of coagulant ${ }^{1}$ during $90 \mathrm{~d}$ of ripening

\begin{tabular}{|c|c|c|c|c|c|c|}
\hline Variable $^{2}$ & Day & A0 & A 25 & A50 & A75 & A100 \\
\hline & 30 & $7.04 \pm 1.32^{\mathrm{b}, \mathrm{A}}$ & $8.11 \pm 0.06^{\mathrm{b}, \mathrm{A}}$ & $7.65 \pm 0.81^{\mathrm{b}, \mathrm{A}}$ & $9.09 \pm 0.83^{\mathrm{b}, \mathrm{A}}$ & $7.04 \pm 0.14^{\mathrm{b}, \mathrm{A}}$ \\
\hline & 60 & $8.03 \pm 0.05^{\mathrm{b}, \mathrm{A}}$ & $9.32 \pm 1.13^{\mathrm{c}, \mathrm{B}}$ & $8.96 \pm 0.08^{\mathrm{b}, \mathrm{A}}$ & $8.30 \pm 0.11^{\mathrm{b}, \mathrm{A}}$ & $8.43 \pm 0.05^{\mathrm{c}, \mathrm{A}}$ \\
\hline \multirow[t]{3}{*}{ TCA-SN, $\%$ of TN } & 1 & $1.97 \pm 0.05^{\mathrm{a}, \mathrm{AB}}$ & $1.65 \pm 0.16^{\mathrm{a}, \mathrm{A}}$ & $1.95 \pm 0.05^{\mathrm{a}, \mathrm{AB}}$ & $2.82 \pm 0.08^{\mathrm{a}, \mathrm{C}}$ & $2.31 \pm 0.14^{\mathrm{a}, \mathrm{B}}$ \\
\hline & 30 & $4.92 \pm 0.20^{\mathrm{b}, \mathrm{AB}}$ & $4.41 \pm 0.45^{\mathrm{b}, \mathrm{AB}}$ & $3.89 \pm 0.17^{\mathrm{b}, \mathrm{A}}$ & $4.14 \pm 0.38^{\mathrm{b}, \mathrm{AB}}$ & $5.08 \pm 0.26^{\mathrm{b}, \mathrm{B}}$ \\
\hline & 60 & $5.49 \pm 0.32^{\mathrm{b}, \mathrm{A}}$ & $6.36 \pm 0.42^{\mathrm{c}, \mathrm{AB}}$ & $6.07 \pm 0.18^{\mathrm{c}, \mathrm{A}}$ & $8.88 \pm 0.13^{\mathrm{c}, \mathrm{C}}$ & $7.09 \pm 0.20^{\mathrm{c}, \mathrm{B}}$ \\
\hline & 60 & $0.24 \pm 0.01^{\mathrm{b}, \mathrm{A}}$ & $0.42 \pm 0.07^{\mathrm{b}, \mathrm{AB}}$ & $0.58 \pm 0.01^{\mathrm{b}, \mathrm{B}}$ & $0.50 \pm 0.03^{\mathrm{ab}, \mathrm{B}}$ & $0.58 \pm 0.04^{\mathrm{c}, \mathrm{B}}$ \\
\hline & 90 & $0.54 \pm 0.05^{\mathrm{c}, \mathrm{A}}$ & $0.76 \pm 0.02^{\mathrm{c}, \mathrm{AB}}$ & $0.69 \pm 0.01^{\mathrm{c}, \mathrm{AB}}$ & $0.88 \pm 0.20^{\mathrm{b}, \mathrm{AB}}$ & $0.94 \pm 0.02^{\mathrm{d}, \mathrm{B}}$ \\
\hline \multirow{3}{*}{$\begin{array}{l}\text { Residual coagulant } \\
\text { activity, \% }\end{array}$} & 1 & $12.22 \pm 0.43^{\mathrm{a}, \mathrm{A}}$ & $16.79 \pm 0.25^{\mathrm{b}, \mathrm{B}}$ & $30.86 \pm 0.08^{\mathrm{ab}, \mathrm{D}}$ & $24.79 \pm 0.00^{\mathrm{ab}, \mathrm{C}}$ & $31.02 \pm 2.23^{\mathrm{b}, \mathrm{D}}$ \\
\hline & 30 & $11.79 \pm 0.00^{\mathrm{a}, \mathrm{A}}$ & $17.63 \pm 1.10^{\mathrm{b}, \mathrm{A}}$ & $18.60 \pm 3.33^{\mathrm{ab}, \mathrm{A}}$ & $35.74 \pm 1.87^{\mathrm{c}, \mathrm{B}}$ & $30.61 \pm 3.24^{\mathrm{b}, \mathrm{B}}$ \\
\hline & 60 & $18.62 \pm 3.12^{\mathrm{b}, \mathrm{B}}$ & $6.61 \pm 0.12^{\mathrm{a}, \mathrm{A}}$ & $12.89 \pm 0.60^{\mathrm{a}, \mathrm{B}}$ & $22.49 \pm 0.00^{\mathrm{a}, \mathrm{C}}$ & $15.18 \pm 0.10^{\mathrm{a}, \mathrm{B}}$ \\
\hline
\end{tabular}

\footnotetext{
${ }^{\mathrm{a}-\mathrm{d}}$ Means in the same column followed by different lowercase letters represent significant differences $(P<0.05)$.

${ }^{\mathrm{A}-\mathrm{D}}$ Means in the same row followed by different uppercase letters represent significant differences $(P<0.05)$.

${ }^{1} \mathrm{~A} 0=100 \%$ camel chymosin $+0 \%$ calf rennet; A25 $=75 \%$ camel chymosin $+25 \%$ calf rennet; A $50=50 \%$ camel chymosin $+50 \%$ calf rennet; $\mathrm{A} 75=25 \%$ camel chymosin $+75 \%$ calf rennet; and A100 $=0 \%$ camel chymosin $+100 \%$ calf rennet.

${ }^{2} \mathrm{SN}=$ soluble nitrogen; $\mathrm{TN}=$ total nitrogen; $\mathrm{TCA}=$ trichloroacetic acid.
} 


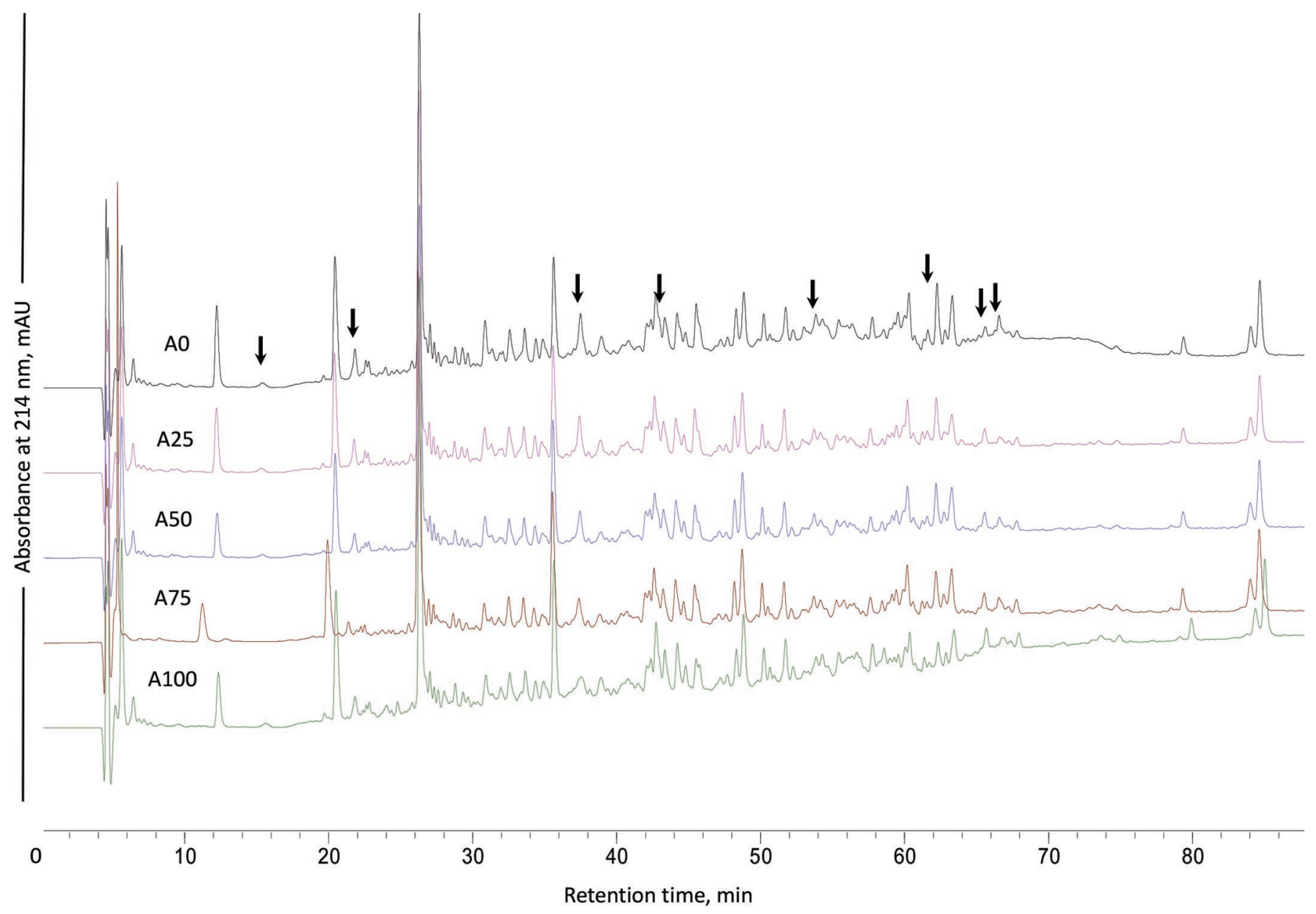

Figure 1. Reversed-phase HPLC peptide profiles of Beyaz peynir made using different blends of coagulant [100\% camel chymosin (A0) + $0 \%$ calf rennet, $75 \%$ camel chymosin $+25 \%$ calf rennet (A25), $50 \%$ camel chymosin $+50 \%$ calf rennet (A50), $25 \%$ camel chymosin $+75 \%$ calf rennet (A75), and $0 \%$ camel chymosin $+100 \%$ calf rennet (A100)] during $90 \mathrm{~d}$ of ripening. Arrows indicate peptides with different heights, which changed with different blends of coagulant.

coagulant used. The cheeses containing higher levels of camel chymosin (A0 and A25) were located on the positive side of $\mathrm{PC} 2$, whereas other cheeses (A50, A75, and A100) containing higher levels of calf rennet appeared on the negative side of $\mathrm{PC} 2$. When compared using a PCA plot of the data, use of camel chymosin or calf rennet resulted in a different peptide profile performed by RP-HPLC in Beyaz peynir, as shown in Figure 2.

Urea-PAGE electrophoretogram of the cheeses (Figure 3a) showed that hydrolysis of $\alpha_{\mathrm{S}_{1}}$-casein in all cheese samples was faster than hydrolysis of $\beta$-casein. Degradation products of the $\alpha_{S 1}$-casein in all cheese samples increased during ripening. $\alpha_{S 1}$-Casein exhibited minimal degradation at the beginning of ripening $(1-30 \mathrm{~d})$ but pronounced degradation after $60 \mathrm{~d}$ of ripening. We determined that different blends of clotting enzymes slightly influenced the hydrolysis of $\beta$ - and $\alpha_{\mathrm{S} 1}$-casein.
Even if the amount of calf chymosin increased, only small differences were observed between the bands of cheeses. On urea-PAGE dendrograms (Figure 3b), the band for A100 cheese varied only slightly from the other samples at $90 \mathrm{~d}$ of ripening. The cheeses were first separated by ripening time on the dendrogram (Figure $3 \mathrm{~b}$ ); however, the effect of the blends of coagulants on the gel patterns was not strong and no grouping between samples was observed. Microbial enzymes in the Beyaz peynir hydrolyzed much more of the $\alpha_{S_{1}}$-casein and $\beta$-casein. These microbial enzymes have higher proteolytic activity than calf or recombinant chymosin (Cepoglu, 2005). However, it was reported that the use of different blends of clotting enzymes and ripening time had significant effects on degradation of $\beta$ - and $\alpha_{\mathrm{S} 1^{-}}$-asein $(P<0.05)$ in a study that examined Malatya cheese (Hayaloglu et al., 2014). The level of intact $\alpha_{\mathrm{S1}^{-}}$ 
casein in Cheddar cheese obtained by calf and camel chymosin after $180 \mathrm{~d}$ of ripening was reported to be 22 and 50\%, respectively (Bansal et al., 2009a). Those authors concluded that camel chymosin could be used to produce Cheddar cheese with lower levels of proteolysis.

\section{Total FAA}

The total FAA levels of the cheeses made using different blends of calf chymosin and camel chymosin are presented in Table 2. Statistical analysis indicated that a significant difference was present in the total FAA levels of all cheeses during ripening $(P<0.05)$. An increase in the level of calf chymosin in the blends of coagulants led to increase the levels of total FAA in cheese during ripening $(P<0.05)$. At the beginning of ripening, the total FAA in A0 (100\% of camel chymosin) was $0.11 \mathrm{mg}$ of Leu/g and that in A100 (100\% calf chymosin) was $0.24 \mathrm{mg}$ of Leu/g. The same changes were observed after 30,60 , and $90 \mathrm{~d}$ of ripening. The level of total FAA in Beyaz peynir changed in positive proportion to the levels of calf chymosin. We found that the higher proteolytic activity and higher level of total FAA of calf chymosin compared with the camel chymosin. As ripening continued, the total FAA increased by the action of primary and secondary proteolysis based on the levels of residual coagulant and enzymes from

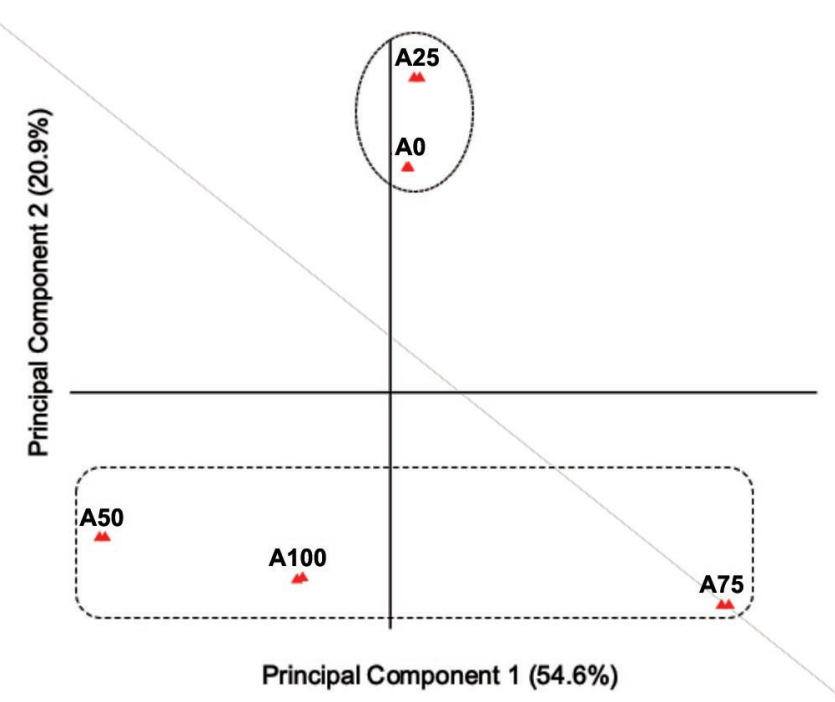

Figure 2. Score plot obtained by principal component analysis of chromatographic data from reversed-phase HPLC profiles of the $\mathrm{pH}$ 4.6-soluble fractions of Beyaz peynir made using different blends of coagulant $[100 \%$ camel chymosin $(\mathrm{A} 0)+0 \%$ calf rennet, $75 \%$ camel chymosin $+25 \%$ calf rennet (A25), $50 \%$ camel chymosin $+50 \%$ calf rennet (A50), $25 \%$ camel chymosin $+75 \%$ calf rennet (A75), and $0 \%$ camel chymosin $+100 \%$ calf rennet (A100)] after $60 \mathrm{~d}$ of ripening. microorganisms, respectively, as reported in various studies (Hayaloglu et al., 2005; O'Mahony et al., 2005; Soltani et al., 2019).

\section{Residual Coagulant Activity}

As shown in Table 2, residual coagulant activity of $\mathrm{A} 0$ and A50 cheeses decreased during the $60 \mathrm{~d}$ of ripening. There were mostly decreases in residual coagulant activity during ripening. Cheeses having a high ratio of calf chymosin have higher residual enzyme activity than cheeses made with camel chymosin. The addition level of the coagulant in cheese making proportionally highlighted the residual coagulant activity in the cheeses (Table 2). The same result was observed by Soltani et al. (2019), who pointed out that the use of Rhizomucor miehei rennet or camel chymosin as the coagulating agent resulted in higher and lower residual coagulant activity in the cheeses, respectively. A study conducted by Bansal et al. (2009b) stated that residual enzyme activity depends not only on the type of cheeses but also on the milk-clotting enzyme types and the temperature used in cheese-making. Visser (1977) reported that the retention of chymosin in cheese is linearly proportional to the amount of chymosin added to milk. Roa et al. (1999) reported that vegetable rennet extracted from Cynara cardunculus flowers, having high levels of proteolytic enzymes, was used in conventional production of (Spanish) La Serena cheese. The presence of a residual coagulating enzyme in cheese and whey was measured. No differences were observed between the residual coagulant activity of La Serena cheese compared with other cheese varieties.

\section{Texture}

Hardness is defined as a measurement of the required force to compress the sample (Hayaloglu et al., 2014), and the hardness values for the samples are shown in Table 3 . The cheeses made using camel chymosin were harder than the calf chymosin counterparts, and the hardness of these samples was significantly influenced by the type of coagulant during ripening $(P<0.05)$. The cheeses containing higher levels of camel chymosin [A0 (harder) or A75 (softer)] were harder than those containing lower levels. Indeed, the same results were obtained by Bansal et al. (2009a), who explained that camel chymosin, with higher milk-clotting activity, produced harder cheese than the calf chymosin. In general, the hardness values of cheeses made using different blends of calf chymosin and camel chymosin decreased during $90 \mathrm{~d}$ of ripening. This may originate from the hydrolysis level of $\alpha_{\mathrm{S1}^{-}}$-casein or the solubility of calcium 
a

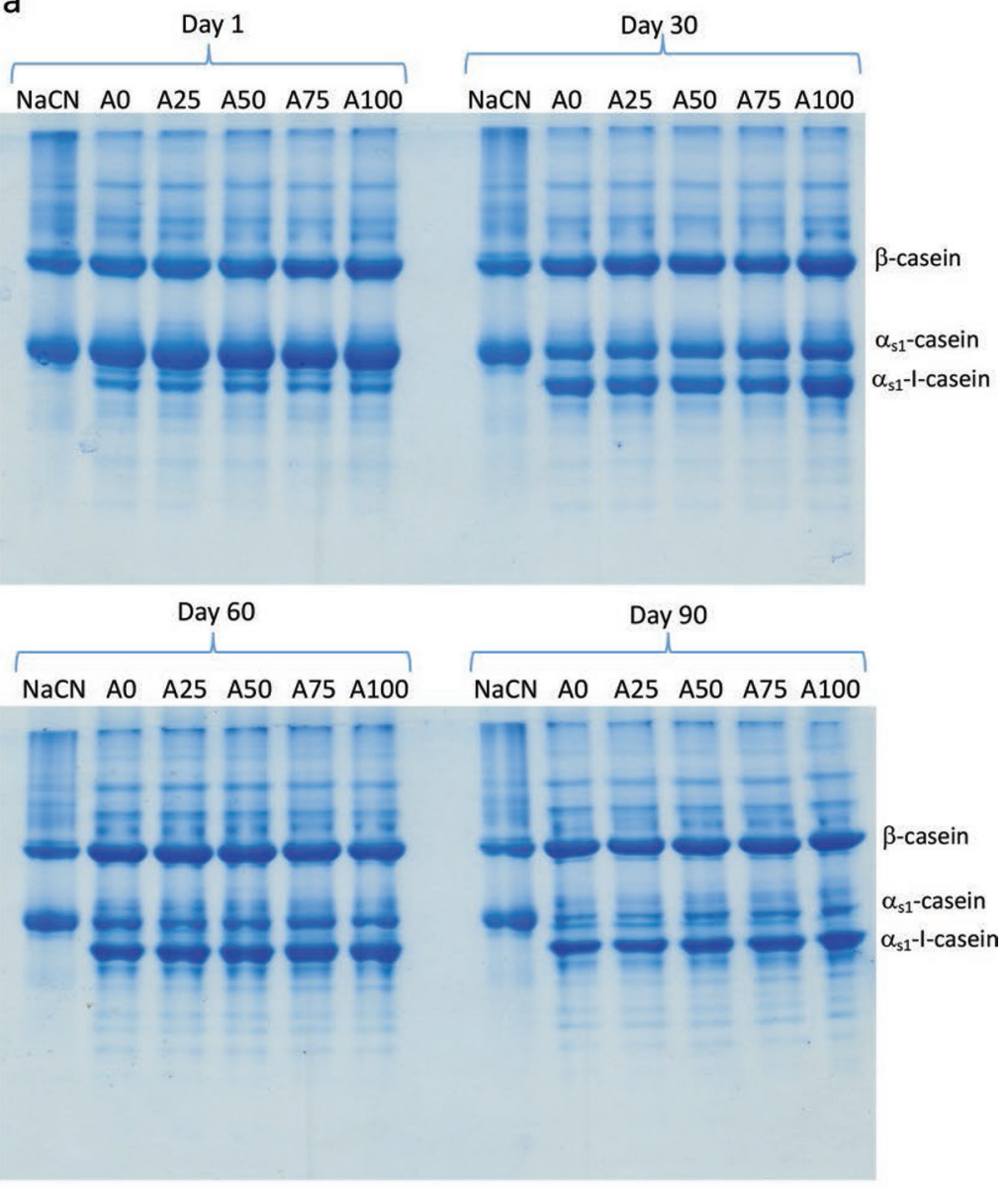

b
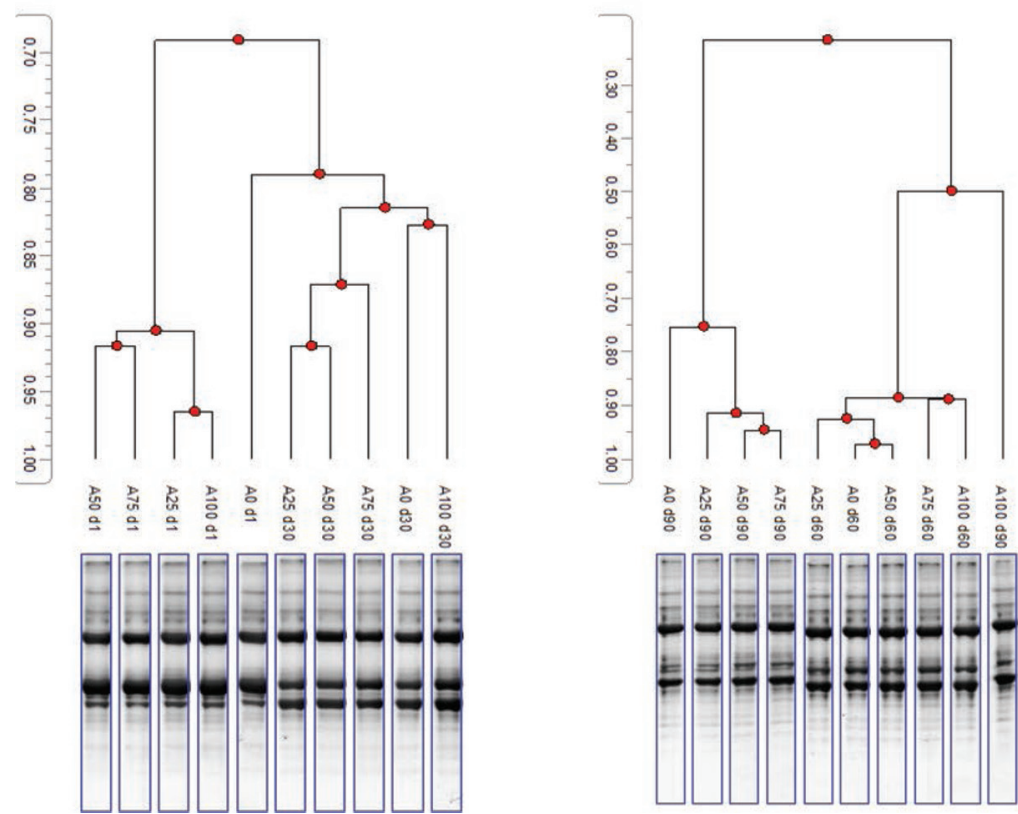

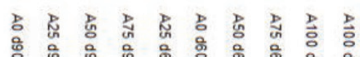

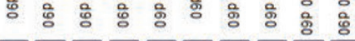

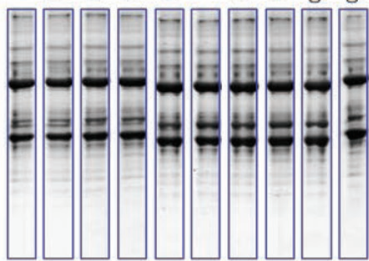

Figure 3. Urea-polyacrylamide gel electrophoretograms (a) and dendrograms (b) of Beyaz peynir made using different blends of coagulant $[100 \%$ camel chymosin (A0) $+0 \%$ calf rennet, $75 \%$ camel chymosin $+25 \%$ calf rennet (A25), $50 \%$ camel chymosin $+50 \%$ calf rennet (A50), $25 \%$ camel chymosin $+75 \%$ calf rennet (A75), and $0 \%$ camel chymosin $+100 \%$ calf rennet (A100)] during 90 d of ripening. 
Table 3. Meltability and texture values of Beyaz peynir made using blends of coagulant ${ }^{1}$ during $90 \mathrm{~d}$ of ripening

\begin{tabular}{|c|c|c|c|c|c|c|}
\hline Variable & Day & $\mathrm{A} 0$ & $\mathrm{~A} 25$ & A 50 & A75 & A100 \\
\hline \multirow{2}{*}{ Hardness, N } & 30 & $3.25 \pm 0.10^{\mathrm{c}, \mathrm{BC}}$ & $3.49 \pm 0.04^{\mathrm{c}, \mathrm{C}}$ & $2.98 \pm 0.10^{\mathrm{c}, \mathrm{B}}$ & $2.53 \pm 0.07^{\mathrm{b}, \mathrm{A}}$ & $2.81 \pm 0.14^{\mathrm{c}, \mathrm{AB}}$ \\
\hline & 60 & $2.26 \pm 0.00^{\mathrm{b}, \mathrm{B}}$ & $2.48 \pm 0.17^{\mathrm{b}, \mathrm{B}}$ & $1.86 \pm 0.01^{\mathrm{b}, \mathrm{A}}$ & $2.32 \pm 0.25^{\mathrm{b}, \mathrm{AB}}$ & $1.86 \pm 0.07^{\mathrm{b}, \mathrm{A}}$ \\
\hline \multirow[t]{3}{*}{ Gumminess, N } & 1 & $1.16 \pm 0.27^{\mathrm{b}, \mathrm{B}}$ & $0.99 \pm 0.17^{\mathrm{c}, \mathrm{AB}}$ & $0.85 \pm 0.10^{\mathrm{c}, \mathrm{AB}}$ & $0.50 \pm 0.11^{\mathrm{b}, \mathrm{A}}$ & $0.47 \pm 0.04^{\mathrm{d}, \mathrm{A}}$ \\
\hline & 30 & $0.49 \pm 0.12^{\mathrm{a}, \mathrm{A}}$ & $0.39 \pm 0.14^{\mathrm{b}, \mathrm{A}}$ & $0.37 \pm 0.00^{\mathrm{b}, \mathrm{A}}$ & $0.21 \pm 0.11^{\mathrm{ab}, \mathrm{A}}$ & $0.21 \pm 0.04^{\mathrm{c}, \mathrm{A}}$ \\
\hline & 60 & $0.19 \pm 0.12^{\mathrm{a}, \mathrm{A}}$ & $0.15 \pm 0.06^{\mathrm{a}, \mathrm{A}}$ & $0.09 \pm 0.02^{\mathrm{a}, \mathrm{A}}$ & $0.15 \pm 0.08^{\mathrm{a}, \mathrm{A}}$ & $0.09 \pm 0.03^{\mathrm{b}, \mathrm{A}}$ \\
\hline \multirow{3}{*}{ Meltability, mm } & 30 & $24.15 \pm 0.71^{\mathrm{a}, \mathrm{A}}$ & $24.62 \pm 0.30^{\mathrm{a}, \mathrm{A}}$ & $24.92 \pm 0.12^{\mathrm{a}, \mathrm{A}}$ & $28.06 \pm 0.07^{\mathrm{b}, \mathrm{C}}$ & $26.48 \pm 0.11^{\mathrm{b}, \mathrm{B}}$ \\
\hline & 60 & $25.94 \pm 0.14^{\mathrm{a}, \mathrm{A}}$ & $28.35 \pm 0.14^{\mathrm{b}, \mathrm{B}}$ & $29.34 \pm 0.21^{\mathrm{b}, \mathrm{BC}}$ & $29.67 \pm 0.02^{\mathrm{c}, \mathrm{C}}$ & $31.84 \pm 0.70^{\mathrm{c}, \mathrm{D}}$ \\
\hline & 90 & $37.78 \pm 1.49^{\mathrm{b}, \mathrm{B}}$ & $39.93 \pm 1.52^{\mathrm{c}, \mathrm{AB}}$ & $39.35 \pm 2.16^{\mathrm{c}, \mathrm{AB}}$ & $42.96 \pm 0.25^{\mathrm{d}, \mathrm{AB}}$ & $44.16 \pm 0.40^{\mathrm{d}, \mathrm{A}}$ \\
\hline
\end{tabular}

${ }^{\mathrm{a}-\mathrm{d}}$ Means in the same column followed by different lowercase letters represent significant differences $(P<0.05)$.

${ }^{\mathrm{A}, \mathrm{B}}$ Means in the same row followed by different uppercase letters represent significant differences $(P<0.05)$.

${ }^{1} \mathrm{~A} 0=100 \%$ camel chymosin $+0 \%$ calf rennet; A25 $=75 \%$ camel chymosin $+25 \%$ calf rennet; A $50=50 \%$ camel chymosin $+50 \%$ calf rennet; $\mathrm{A} 75=25 \%$ camel chymosin $+75 \%$ calf rennet; and A100 $=0 \%$ camel chymosin $+100 \%$ calf rennet.

(that decreases in insoluble calcium content), or both, in the cheese (Hayaloglu et al., 2014). The same changes were observed in Kashar cheese samples throughout ripening (Yasar and Güzeler, 2011) and these results are in accordance with the present study. O'Mahony et al. (2005) reported that hardness values of Cheddar cheese decreased as ripening progressed from 1 to $90 \mathrm{~d}$. The effects of different blends of coagulating enzymes on hardness of the cheese were statistically significant $(P<0.05)$. These results are in agreement with those of Hayaloglu et al. (2014).

Gumminess values of the cheeses made using different blends of calf chymosin and camel chymosin during $90 \mathrm{~d}$ of ripening are presented in Table 3. These values decreased for all cheeses during $90 \mathrm{~d}$ of ripening. Although significant differences in gumminess values of cheeses produced using different coagulating enzyme mixtures were seen at the beginning of ripening, no significant difference was observed among gumminess values after $30 \mathrm{~d}$ of ripening. A significant reduction in gumminess values of Malatya (Hayaloglu et al., 2014) and Cheddar (O'Mahony et al., 2005) cheeses was also noticed during ripening. Yasar and Güzeler (2011) reported that gumminess values of Kashar cheese decreased during ripening. In this study, cheeses made with $100 \%$ camel chymosin were significantly harder, more cohesive, and chewier than the cheeses made with $100 \%$ calf chymosin, especially at $90 \mathrm{~d}$ of ripening.

\section{Meltability}

Meltability values of the cheese produced using coagulating enzymes at different levels and changes during $90 \mathrm{~d}$ of ripening are given in Table 3 . The meltability values of all cheeses increased significantly during ripening $(P<0.05)$. The blends of different enzymes significantly influenced the meltability values of the cheeses $(P<0.05)$. After $60 \mathrm{~d}$ of ripening (Table 3 ), an increase in the meltability values of cheese was associated with an increasing rate of calf chymosin in the coagulant formula. This is because the effect of the calf chymosin on meltability is higher than camel chymosin. Some studies reported an increase in the meltability during ripening due to the hydrolysis of $\alpha_{S 1}$-casein and solubility of calcium (Yasar and Güzeler, 2011; Hayaloglu et al., 2014). Other studies reported that meltability values increase because of proteolysis in the cheese matrix as well as an increase in the partial solubility of colloidal calcium phosphate of cheese (O'Mahony et al., 2005; Madadlou et al., 2005; Sahan et al., 2008).

\section{Microstructure}

Microstructure images of the cheeses made with different blends of coagulants were observed by the scanning electron microscopy and the $10,000 \times$ magnification images are shown in Figure 4. Each cheese type has a typical structural image that exhibits its biological and chemical variation (Madadlou et al., 2005). Changes in the coagulant formulas did not reflect the microstructure of cheeses at a significant level, however, and only small differences were observed among the images. As can be seen in Figure 4, A0 cheese sample has smaller spaces and a tighter microstructure. Spaces seem to be more evident in cheese sample A25 than in other cheese samples. The spaces in cheeses made with camel chymosin were more evident than those in cheeses made with calf chymosin. Malatya cheeses produced using calf chymosin were bigger and had a tighter microstructure than cheeses produced using microbial chymosin 
(Hayaloglu et al., 2014). It was determined that enzyme concentration has an effect on cheese microstructure (Madadlou et al., 2005; Hayaloglu et al., 2014).

\section{Sensory Evaluation}

Beyaz peynir samples were evaluated in terms of color/appearance, structure/texture, flavor, and overall acceptability (Table 4). Beyaz peynir is characterized as being "porcelain white" in color, with a close texture, an acid and salty taste, and cubic or rectangular in shape by the Turkish Food Codex. Color and appearance values decreased in cheeses with different blends of coagulants during ripening. Cheeses with different blends of coagulants had no significant effects on the
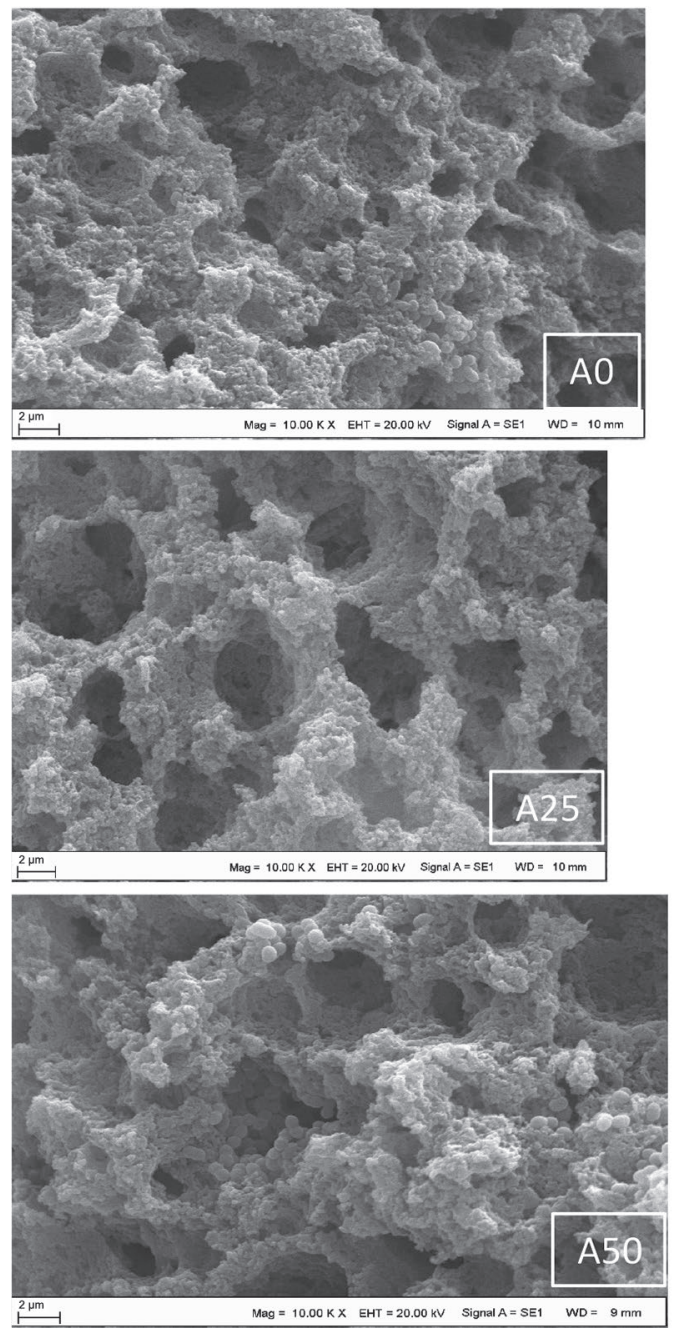

structure and texture values of the cheeses $(P>0.05)$. Although fluctuations were observed in the structure and texture of cheeses during ripening, the values decreased toward the end of ripening. Degradation products resulting from the action of enzymes lead to the formation of different flavors. One of the most common taste problems is bitterness during ripening. It appears that the blends of the 2 enzymes do not affect the flavor values of the cheese. Hayaloglu et al. (2005) reported that the use of different starters did not significantly influence the sensory attributes. In another study, sensory results showed that cheeses produced with camel chymosin were firmer and less sticky than those made with bovine calf chymosin during ripening (Moynihan et al., 2014). No substantial differences were observed
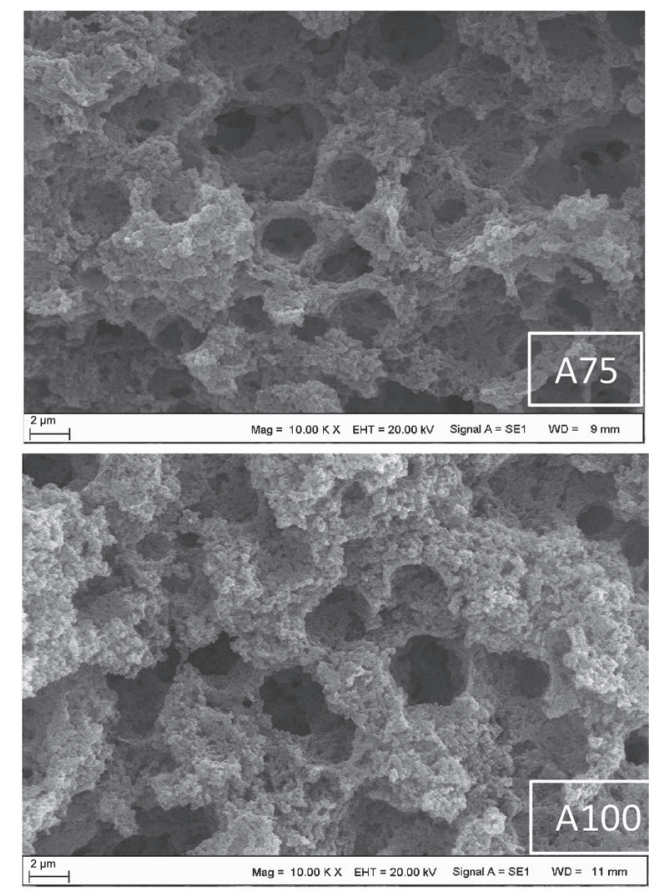

Figure 4. Scanning electron micrographs of Beyaz peynir made using different blends of coagulant $[100 \%$ camel chymosin (A0) $+0 \%$ calf rennet, $75 \%$ camel chymosin $+25 \%$ calf rennet (A25), $50 \%$ camel chymosin $+50 \%$ calf rennet (A 50 ), $25 \%$ camel chymosin $+75 \%$ calf rennet (A75), and 0\% camel chymosin $+100 \%$ calf rennet (A100)] during $90 \mathrm{~d}$ of ripening. 
Table 4. Sensory properties of Beyaz peynir made using different blends of coagulant ${ }^{1}$ during $90 \mathrm{~d}$ of ripening, rated on a scale of 0 to 5

\begin{tabular}{|c|c|c|c|c|c|c|}
\hline Variable & Day & $\mathrm{A} 0$ & $\mathrm{~A} 25$ & A50 & A75 & A100 \\
\hline \multirow{2}{*}{ Color and appearance } & 30 & $5.00 \pm 0.21^{\mathrm{b}, \mathrm{A}}$ & $5.00 \pm 0.14^{\mathrm{d}, \mathrm{A}}$ & $5.00 \pm 0.14^{\mathrm{c}, \mathrm{A}}$ & $5.00 \pm 0.15^{\mathrm{c}, \mathrm{A}}$ & $5.00 \pm 0.15^{\mathrm{d}, \mathrm{A}}$ \\
\hline & 60 & $4.50 \pm 0.21^{\mathrm{b}, \mathrm{A}}$ & $4.50 \pm 0.12^{\mathrm{b}, \mathrm{A}}$ & $3.75 \pm 0.14^{\mathrm{a}, \mathrm{A}}$ & $4.25 \pm 0.14^{\mathrm{b}, \mathrm{A}}$ & $4.00 \pm 0.14^{\mathrm{b}, \mathrm{A}}$ \\
\hline \multirow[t]{3}{*}{ Structure and texture } & 1 & $3.60 \pm 0.85^{\mathrm{a}, \mathrm{A}}$ & $4.20 \pm 0.85^{\mathrm{a}, \mathrm{A}}$ & $3.70 \pm 0.71^{\mathrm{a}, \mathrm{A}}$ & $4.10 \pm 0.71^{\mathrm{b}, \mathrm{A}}$ & $3.70 \pm 0.71^{\mathrm{a}, \mathrm{A}}$ \\
\hline & 30 & $3.10 \pm 0.14^{\mathrm{a}, \mathrm{A}}$ & $4.15 \pm 0.49^{\mathrm{a}, \mathrm{A}}$ & $3.95 \pm 0.64^{\mathrm{a}, \mathrm{A}}$ & $4.40 \pm 0.85^{\mathrm{b}, \mathrm{A}}$ & $3.70 \pm 0.85^{\mathrm{a}, \mathrm{A}}$ \\
\hline & 60 & $3.00 \pm 0.15^{\mathrm{a}, \mathrm{A}}$ & $3.00 \pm 0.30^{\mathrm{a}, \mathrm{A}}$ & $3.50 \pm 0.30^{\mathrm{a}, \mathrm{A}}$ & $3.50 \pm 0.40^{\mathrm{ab}, \mathrm{A}}$ & $2.75 \pm 0.3^{\mathrm{a}, \mathrm{A}}$ \\
\hline \multirow{2}{*}{ Flavor } & 60 & $5.50 \pm 0.40^{\mathrm{a}, \mathrm{B}}$ & $4.75 \pm 0.28^{\mathrm{ab}, \mathrm{B}}$ & $5.25 \pm 0.14^{\mathrm{b}, \mathrm{B}}$ & $2.75 \pm 0.50^{\mathrm{a}, \mathrm{A}}$ & $3.25 \pm 0.5^{\mathrm{a}, \mathrm{AB}}$ \\
\hline & 90 & $5.00 \pm 0.40^{\mathrm{a}, \mathrm{B}}$ & $3.80 \pm 0.28^{\mathrm{a}, \mathrm{AB}}$ & $3.40 \pm 0.14^{\mathrm{a}, \mathrm{A}}$ & $4.00 \pm 0.50^{\mathrm{b}, \mathrm{AB}}$ & $4.20 \pm 0.5^{\mathrm{ab}, \mathrm{AB}}$ \\
\hline \multirow[t]{4}{*}{ Overall acceptability } & 1 & $4.40 \pm 0.28^{\mathrm{b}, \mathrm{A}}$ & $3.90 \pm 0.14^{\mathrm{c}, \mathrm{A}}$ & $3.80 \pm 0.57^{\mathrm{a}, \mathrm{A}}$ & $3.90 \pm 0.42^{\mathrm{b}, \mathrm{A}}$ & $4.10 \pm 0.42^{\mathrm{b}, \mathrm{A}}$ \\
\hline & 30 & $3.45 \pm 0.07^{\mathrm{a}, \mathrm{AB}}$ & $3.90 \pm 0.14^{\mathrm{c}, \mathrm{B}}$ & $3.00 \pm 0.27^{\mathrm{a}, \mathrm{A}}$ & $4.08 \pm 0.45^{\mathrm{b}, \mathrm{B}}$ & $3.73 \pm 0.25^{\mathrm{b}, \mathrm{B}}$ \\
\hline & 60 & $3.25 \pm 0.07^{\mathrm{a}, \mathrm{B}}$ & $2.75 \pm 0.14^{\mathrm{a}, \mathrm{AB}}$ & $3.50 \pm 0.27^{\mathrm{a}, \mathrm{B}}$ & $2.25 \pm 0.42^{\mathrm{a}, \mathrm{A}}$ & $2.25 \pm 0.22^{\mathrm{a}, \mathrm{A}}$ \\
\hline & 90 & $4.00 \pm 0.07^{\mathrm{b}, \mathrm{B}}$ & $3.40 \pm 0.14^{\mathrm{b}, \mathrm{A}}$ & $3.60 \pm 0.27^{\mathrm{a}, \mathrm{A}}$ & $3.20 \pm 0.42^{\mathrm{ab}, \mathrm{A}}$ & $4.00 \pm 0.22^{\mathrm{b}, \mathrm{B}}$ \\
\hline
\end{tabular}

${ }^{\mathrm{a}-\mathrm{d}}$ Means in the same column followed by different lowercase letters represent significant differences $(P<0.05)$.

${ }^{\mathrm{A}-\mathrm{D}}$ Means in the same row followed by different uppercase letters represent significant differences $(P<0.05)$.

${ }^{1} \mathrm{~A} 0=100 \%$ camel chymosin $+0 \%$ calf rennet; A $25=75 \%$ camel chymosin $+25 \%$ calf rennet; A $50=50 \%$ camel chymosin $+50 \%$ calf rennet; $\mathrm{A} 75=25 \%$ camel chymosin $+75 \%$ calf rennet; and A100 $=0 \%$ camel chymosin $+100 \%$ calf rennet.

in the results of sensory analysis between cheeses made with camel chymosin and calf chymosin during $90 \mathrm{~d}$ of ripening $(P>0.05)$.

\section{CONCLUSIONS}

Cheeses made with higher levels of calf chymosin produced higher levels of $\mathrm{pH} 4.6-\mathrm{SN}$ and 12\% TCASN fractions than cheeses made with camel chymosin. Urea-PAGE gel electrophoresis and RP-HPLC peptide profiles of the cheeses showed that casein hydrolysis was slightly influenced by different blends of coagulant mixtures at all stages of ripening. Cheeses containing a large amount of calf chymosin had higher levels of total FAA and higher meltability values than cheeses containing higher ratios of camel chymosin. Residual coagulant activity of the cheeses was influenced by different amounts of the coagulant. The cheeses showing a high ratio of calf chymosin had higher residual coagulant activity. Cheeses produced by calf chymosin were harder than the camel chymosin counterparts. The same trend was observed for gumminess values, which were affected by different blends of coagulants. That is, the cheeses containing calf chymosin at a high proportion had a softer structure compared with the cheeses containing a larger level of camel chymosin. The use of different coagulant enzyme mixtures had no significant effect on sensory properties of the cheeses and only small effects on the microstructure of the cheeses. In conclusion, the residual coagulant activity of milk-clotting enzymes is highly related to its addition level and milk-clotting power. Considering the data obtained from this study, we suggest that decreasing the composition of camel chymosin and using calf chymosin at a higher proportion in the manufacture of Beyaz peynir may increase proteolysis and improve the functional properties.

\section{ACKNOWLEDGMENTS}

This work was supported by Inonu University Scientific and Research Unit (project numbers 2014/06 and 2015/14). The authors also acknowledge the contributions of O. S. Boran (Ministry of Agriculture and Forestry, Malatya Directorate of Provincial Agriculture and Forestry, Malatya, Turkey) for his assistance during cheese making.

\section{REFERENCES}

Ahmed, S. A., H. R. Wehaidy, O. A. Ibrahim, S. A. El Ghani, and M. A. El-Hofi. 2016. Novel milk-clotting enzyme from Bacillus stearothermophilus as a coagulant in UF-white soft cheese. Biocatal. Agric. Biotechnol. 7:241-249.

Akkerman, M., L. S. Kristensen, L. Jespersen, M. B. Ryssel, A. Mackie, N. N. Larsen, and L. A. Mielby. 2017. Interaction between sodium chloride and texture in semi-hard Danish cheese as affected by brining time, DL-starter culture, chymosin type and cheese ripening. Int. Dairy J. 70:34-45.

Alichanidis, E., E. M. Anifantakis, A. Polychroniadou, and M. Nanou. 1984. Suitability of some microbial coagulants for Feta cheese manufacture. J. Dairy Res. 51:141-147.

Bansal, N., M. A. Drake, P. Piraino, M. L. Broe, M. Harboe, P. F. Fox, and P. L. H. McSweeney. 2009a. Suitability of recombinant camel (Camelus dromedarius) chymosin as a coagulant for Cheddar cheese. Int. Dairy J. 19:510-517.

Bansal, N., P. F. Fox, and P. L. H. McSweeney. 2007. Factors affecting the retention of rennet in cheese curd. J. Agric. Food Chem. 55:9219-9225.

Bansal, N., P. F. Fox, and P. L. H. McSweeney. 2009b. Comparison of the level of residual coagulant activity in different cheese varieties. J. Dairy Res. 76:290-293. 
Borsting, M. W., K. B. Qvist, and Y. Ardö. 2014. Influence of pH on retention of camel chymosin in curd. Int. Dairy J. 38:133-135.

Broome, M. C., and G. K. Y. Limsowtin. 1998. Milk coagulants. Aust. J. Dairy Technol. 53:188-190.

Bruno, M. A., C. M. Lazza, M. E. Errasti, L. M. López, N. O. Caffini, and M. F. Pardo. 2010. Milk clotting and proteolytic activity of an enzyme preparation from Bromelia hieronymi fruits. Lebensm. Wiss. Technol. 43:695-701.

Cepoglu, F. 2005. Researching the possibilities of the recombinant chymosin usage in White cheese production. Master's Thesis, Department of Food Engineering, Harran University, Şanlıurfa, Turkey.

Cepoglu, F., and M. B. Güler-Akın. 2013. Effects of coagulating enzyme types (commercial calf rennet, Aspergillus niger var. Awamori as recombinant chymosin and Rhizomucor miehei as microbial rennet) on the chemical and sensory characteristics of White pickled cheese. Afr. J. Biotechnol. 12:5588-5594.

Hayaloglu, A. A. 2017. Cheese varieties ripened under brine. Pages 997-1040 in Cheese: Chemistry, Physics and Microbiology. 4th ed. P. L. H. McSweeney, P. F. Fox, P. D. Cotter, and D. W. Everett, ed. Elsevier Academic Press, London, UK.

Hayaloglu, A. A., M. Guven, and P. F. Fox. 2002. Microbiological biochemical and technological properties of Turkish White cheese "Beyaz Peynir". Int. Dairy J. 12:635-648.

Hayaloglu, A. A., M. Guven, P. F. Fox, and P. L. H. McSweeney. 2005. Influence of starters on chemical, biochemical, and sensory changes in Turkish White brined cheese during ripening. J. Dairy Sci. 88:3460-3474.

Hayaloglu, A. A., B. Karatekin, and H. Gurkan. 2014. Thermal stability of chymosin or microbial coagulant in the manufacture of Malatya, a Halloumi type cheese: Proteolysis, microstructure and functional properties. Int. Dairy J. 38:1-9.

Hurley, M. J., B. M. O'Driscoll, A. L. Kelly, and P. L. H. McSweeney. 1999. Novel assay for the determination of residual coagulant activity in cheese. Int. Dairy J. 9:553-558.

Hynes, E. R., L. Aparo, and M. C. Candioti. 2004. Influence of residual milk-clotting enzyme on $\alpha_{S 1}$ casein hydrolysis during ripening of Reggianito Argentino cheese. J. Dairy Sci. 87:565-573.

Jensen, J. L., A. Molgaard, J. C. N. Poulsen, M. K. Harboe, J. B. Simonsen, and A. M. Lorentzen. 2013. Camel and bovine chymosin: The relationship between their structures and cheese-making properties. Acta Crystallogr. D Biol. Crystallogr. 69:901-913.

Kappeler, S. R., H. J. M. Van der Brink, H. Rahbek-Nielsen, Z. Farah, Z. Puhan, E. B. Hansen, and E. Johansen. 2006. Characterization of recombinant camel chymosin reveals superior properties for the coagulation of bovine and camel milk. Biochem. Biophys. Res. Commun. 342:647-654.

Kumar, A., J. Sharma, A. K. Mohanty, S. Grover, and V. K. Batish. 2006. Purification and characterization of milk clotting enzyme from goat (Capra hircus). Comp. Biochem. Physiol. B Biochem. Mol. Biol. 145:108-113.

Lane, C. N., P. F. Fox, D. E. Johnston, and P. L. H. McSweeney. 1997. Contribution of coagulant to proteolysis and textural changes in Cheddar cheese during ripening. Int. Dairy J. 7:453-464.

Madadlou, A., A. Khosrowshahi, and M. E. Mousavi. 2005. Rheology, microstructure, and functionality of low-fat Iranian white cheese made with different concentrations of rennet. J. Dairy Sci. 88:3052-3062.

Møller, K. K., F. P. Rattray, J. C. Sørensen, and Y. Ardö. 2012. Comparison of the hydrolysis of bovine $\kappa$-casein by camel and bovine chymosin: A kinetic and specificity study. J. Agric. Food Chem. 60:5454-5460

Moschopoulou, E. 2011. Characteristics of rennet and other enzymes from small ruminants used in cheese production. Small Rumin. Res. 101:188-195.

Moynihan, A. C., S. Govindasamy-Lucey, J. J. Jaeggi, M. E. Johnson, J. A. Lucey, and P. L. H. McSweeney. 2014. Effect of camel chymosin on the texture, functionality, and sensory properties of low-moisture, part-skim Mozzarella cheese. J. Dairy Sci. 97:85-96.

O'Mahony, J. A., J. A. Lucey, and P. L. H. McSweeney. 2005. Chymosin-mediated proteolysis, calcium solubilization, and texture development during the ripening of Cheddar Cheese. J. Dairy Sci. 88:3101-3114.

O'Mahony, J. A., M. J. Sousa, and P. L. H. McSweeney. 2003. Proteolysis in miniature Cheddar-type cheeses made using blends of chymosin and Cynara cardunculus proteinases as coagulant. Int. J. Dairy Technol. 56:52-58.

Oluk, A. C., M. Güven, and A. A. Hayaloglu. 2014. Proteolysis texture and micro structure of low-fat Tulum cheese affected by exopolysaccharide-producing cultures during ripening. Int. J. Food Sci. Technol. 49:435-443.

Roa, I., M. B. López, and F. J. Mendiola. 1999. Residual clotting activity and ripening properties of vegetable rennet from Cynara cardunculus in La Serena cheese. Food Res. Int. 32:413-419.

Sahan, N., K. Yasar, A. A. Hayaloglu, O. B. Karaca, and A. Kaya. 2008. Influence of fat replacers on chemical composition, proteolysis, texture profiles, meltability and sensory properties of low-fat Kashar cheese. J. Dairy Res. 75:1-7.

Sahingil, D., A. A. Hayaloglu, O. Simsek, and B. Ozer. 2014. Changes in volatile composition, proteolysis and textural and sensory properties of white-brined cheese: effects of ripening temperature and adjunct culture. Dairy Sci. Technol. 94:603-623.

Soltani, M., D. Sahingil, Y. Gokce, and A. A. Hayaloglu. 2019. Effect of blends of camel chymosin and microbial rennet (Rhizomucor miehei) on chemical composition, proteolysis and residual coagulant activity in Iranian Ultrafiltered White cheese. J. Food Sci. Technol. https://doi.org/10.1007/s13197-018-3513-3.

Sousa, M. J., Y. Ardö, and P. L. H. McSweeney. 2001. Advances in the study of proteolysis during cheese ripening. Int. Dairy J. 11:327345 .

Sousa, M. J., and F. X. Malcata. 1997. Comparison of plant and animal rennets in terms of microbiological, chemical, and proteolysis characteristics of Ovine cheese. J. Agric. Food Chem. 45:74-81.

Visser, F. M. W. 1977. Contribution of enzymes from rennet, starter bacteria and milk to proteolysis and flavour development in Gouda cheese. 1. Description of cheese and aseptic cheesemaking techniques. Neth. Milk Dairy J. 31:120-133.

Yasar, K., and N. Güzeler. 2011. Effects of coagulant type on the physicochemical and organoleptic properties of Kashar cheese. Int. J. Dairy Technol. 64:372-379. 